\title{
Pasture growth and quality on Southland and Otago dairy farms
}

\author{
D. E. DALLEY ${ }^{1}$ and T. GEDDES ${ }^{2}$ \\ ${ }^{1}$ DairyNZ, PO Box 160, Lincoln University, 7647 \\ ${ }^{2}$ DairyNZ, 70 Forth Street, Invercargill, 9810 \\ dawn.dalley@dairynz.co.nz
}

\begin{abstract}
There is debate on how pasture growth rates and annual production on dairy farms in Southland/Otago compare to the comprehensive data collected at AgResearch Woodlands under sheep grazing. Additionally, there are no good data on seasonal variation in dairy pasture quality from the region. Six farms in different geographical regions of Southland and south and west Otago were monitored from spring 2007 until May 2012 to measure pasture growth rate, soil temperature and pasture nutrient composition (with the exception of south Otago). Pasture growth rates varied between farms and between years. The highest growth rates were recorded in coastal Southland and the lowest in northern Southland. Rainfall and soil temperature differences explained some of the changes in pasture growth rate throughout the seasons. Sharp drops in pasture quality in early summer were recorded on all farms. Considerable variation in pasture growth rate occurs across the Southland/Otago regions. Times of year when the greatest variability occurs have now been identified for each region.
\end{abstract}

Keywords: Southland, Otago, pasture growth, pasture quality, dairy

\section{Introduction}

Southland and Otago have seen significant growth in dairy farming over the last 15-20 years and have further potential to increase production due to land availability and affordability for dairy conversion. The region now produces $17 \%$ of New Zealand's milksolids (DairyNZ 2011). Dairy farmers new to the region identified a scarcity of basic information on pasture growth and quality for the region. Such information is critical for annual feed budgeting, farm system setup (e.g. calving date, stocking rate), and for weekly farm management decisions. Prior to this study the only published growth rate values for Southland were from Radcliffe (1974). However, there is also comprehensive pasture growth rate information from AgResearch Woodlands under sheep grazing (Smith 2012). Reliable growth rate information for the region and data on pasture quality changes will give farmers more confidence in making feeding decisions and help them to evaluate the applicability of research from other regions for their situation. This paper reports the pasture growth rates and quality from five commercially operated dairy farms across the Southland and west Otago regions from spring 2007 to May 2012. In addition, growth rate data from the Telford Rural Polytechnic dairy farm at Balclutha (south Otago) was included in the study from 2008.

\section{Materials and Methods}

Topoclimate and soil type information were used to identify geographically different regions within the Southland and south and west Otago regions of New Zealand. The five regions selected were coastal Southland (COAST), eastern Southland (EAST), central Southland (CENT), northern Southland (NTH) and west Otago (WO). Four monitor farms were selected according to size, location, stocking rate, farming system, record keeping, soil type and willingness of the farmer to use the information generated. The fifth and sixth farms were the Southland Demonstration Farm (SDF; COAST) and the Telford Rural Polytechnic dairy farms (South Otago; SO), respectively. Details of the farms are reported in Table 1. AgResearch Woodlands pasture growth data from fortnightly cage cut measurements (Smith 2012) during the monitoring period (Chris Smith, pers. comm.) and the longterm average (1978-2007) monthly growth at the commencement of the project were also accessed for comparison.

Pasture growth rates were determined by weekly assessment of the pasture height in every paddock on each farm using a rising plate meter (Thomson et al. 2001). Pasture mass (kg DM/ha) was estimated using the rising plate meter winter equation: (height $\times 140$ ) +500 , throughout the season. Farm walks on the four commercially operated dairy farms were undertaken by the same person each week. Growth rate was calculated using the Pasture Coach Software (Version 5.0, AgSoft Solutions), excluding data from paddocks that had been grazed between measurements. Grazing date and post-grazing residual pasture mass were not recorded in the software during the growth rate calculations. Pasture Coach only uses paddocks that have not been 


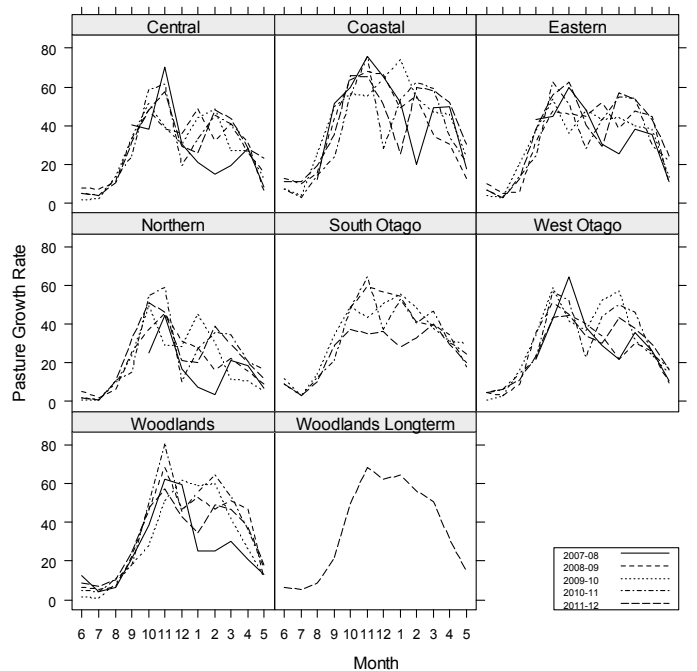

Figure 1. Average monthly pasture growth rate $(\mathrm{kg} / \mathrm{ha} /$ day $)$ for seven sites across Southland and south and west Otago from August 2007 to May 2012 and Woodlands longterm average growth rates under sheep grazing from 1978 to 2007.

grazed between measurements in the average growth rate calculation and to calculate annual DM production multiplies the paddock average growth rate for a month by the number of days in that month.

Data from the SDF and Telford farms were collected and summarised by the respective farm managers. Both farms used the rising plate meter to measure pasture height and Pasture Coach was used to calculate growth rate. At SDF, grazing date and post-grazing residual of paddocks grazed in the previous 7 days were entered into the software for each paddock. Nitrogen (N) fertiliser applications were recorded for each farm. Each fortnight, two pasture samples were collected to grazing height from the next two paddocks to be grazed on the EAST, NTH, CENT and WO farms. These samples were analysed for nutrient composition (near infra-red spectroscopy, ARL Labs, Ravensdown). Soil temperature $(10 \mathrm{~cm})$ was recorded at $10 \mathrm{a} . \mathrm{m}$. on the day

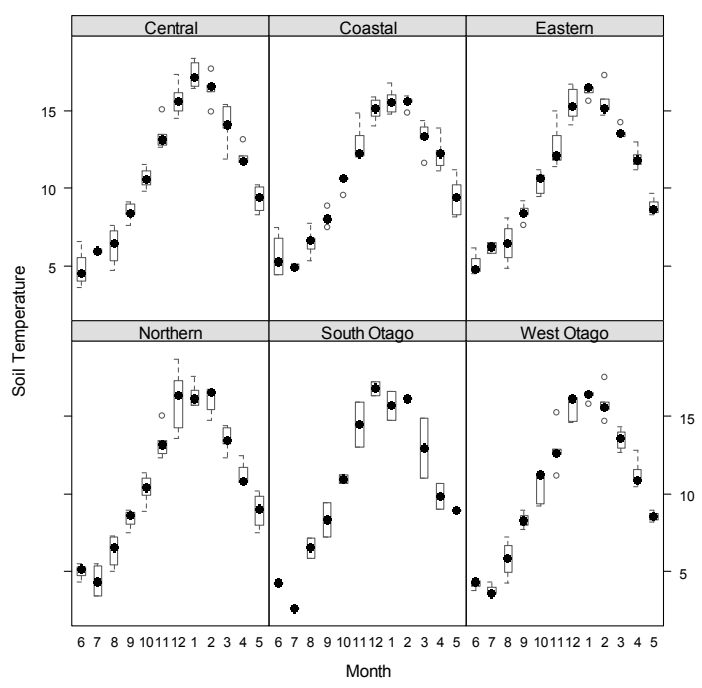

Figure 2. Average monthly soil temperature $(10 \mathrm{~cm}$ at 10 am) for six sites across Southland and south and west Otago from August 2007 to May 2012.

of the farm walk. At the end of each season the annual dry matter (DM) production was calculated for each paddock on the farms.

\section{Results and Discussion}

During the five years of monitoring there were small changes in the management practices implemented on each farm in response to milk price and changes in farming philosophies. Of major note was the reduction in nitrogen fertiliser use on the WO farm from $130 \mathrm{~kg} \mathrm{~N} /$ ha in $2007 / 08$ to only $23 \mathrm{~kg} \mathrm{~N} /$ ha in 2011/12. Similarly the NTH farm had very low N inputs (Table 1) from the start of the study, with no artificial $\mathrm{N}$ fertiliser being applied from June 2009. No nitrogen was used on the pastures monitored at Woodlands.

There was considerable variation in pasture growth rate between regions, and also between years, within a region (Figure 1). All regions had reasonably predictable growth rates through winter and early spring, however late spring and summer growth rates

Table 1. Farm location, size, number of cows milked, average annual nitrogen $(\mathrm{N})$ fertiliser application and rainfall at the closest NIWA climate station to the six farms involved in the study (central - Winton, $25 \mathrm{~km}$; eastern \& coastal - Invercargill Airport, 40 \& 15 km; northern - Mandeville, 16 km; west Otago - Tapanui, 3 km; south Otago - Telford; 1 km).

\begin{tabular}{lcccccc}
\hline & $\begin{array}{c}\text { Area } \\
\text { (effective ha) }\end{array}$ & $\begin{array}{c}\text { No. } \\
\text { cows }\end{array}$ & $\begin{array}{c}\text { Average N use }( \pm \\
\text { s.d.) }(\mathrm{kg} / \mathrm{ha} / \mathrm{yr})\end{array}$ & $\begin{array}{c}\text { Rainfall ( } \pm \text { s.d.) } \\
\mathrm{mm} / \mathrm{annum}\end{array}$ & Location & Farm Type \\
\hline Central Southland & 160 & 450 & $132(40.3)$ & $912(93.2)$ & South Hillend & Commercial \\
Eastern Southland & 143 & 460 & $94(27)$ & $1095(73.6)$ & Seaward Downs & Commercial \\
Coastal Southland & 259 & 760 & $176(50.2)$ & $1095(73.6)$ & Wallacetown & SDF \\
Northern Southland & 138 & 350 & $6(7.6)$ & $919(59.0)$ & Riversdale & Commercial \\
West Otago & 130 & 360 & $60(40)$ & $854(125.4)$ & Tapanui & Commercial \\
South Otago & 166 & 510 & $136(43.7)$ & $674(82.7)$ & Balclutha & Telford \\
\hline
\end{tabular}


were more variable between years. The regions with the least variability were south Otago (SO) and eastern Southland (Table 2). In three of the five years that were monitored, significant periods of low growth occurred between November and March. During 2007/08 the low growth period occurred during February and March, while in 2011/12 it occurred during December and January. The length of the dry period had a large impact on the annual pasture dry matter production. In no one season did all farms have their best annual growth. For west and south Otago the highest annual pasture production was recorded in 2009/10, while for NTH, COAST and Woodlands the best growth year was 2010/11. For EAST and CENT the highest pasture production year was 2011/12.

Estimated annual pasture DM production from the weekly farm walks ranged from $7.6 \pm 0.22 \mathrm{t} \mathrm{DM} /$ ha on the NTH farm to $14.3 \pm 0.27 \mathrm{t} \mathrm{DM} / \mathrm{ha}$ on the COAST property (Table 2). However, the annual growth figures for the EAST, CENT, NTH, SO and WO farms did not align with the estimated growth determined by back calculation from milk yield (Dairybase analysis, data not reported) and when the CENT data were used for Farmax modelling (Dennis et al. 2012) we were unable to model average pasture cover or herd production using the recorded growth rates. On further investigation, the way in which the Pasture Coach programme was used during this project may have contributed to the underestimation of annual yield. When recording the weekly paddock cover data, the option of recording the grazing date and pasture residual was not included for these farms due to the absence of post-grazing residual estimates on individual paddocks immediately after grazing. Since the pasture mass was estimated on the same day each week, in any given week some paddocks were grazed on the day of the farm walk, while others were last grazed 7 days prior. Pastures that are close to being grazed tend to have higher pasture growth rates (Parsons 1994). Therefore for the paddocks grazed within 3 days of the farm walk each week average growth may be underestimated. A better measure of growth rate is achieved when the grazing date and residual option in Pasture Coach are used (C Lewis pers. comm.) The following equation was derived to adjust the estimated growth rate for the calculation of annual DM yield (Table 2$)$ :

Adj GR $=(1+(7 /($ rotation length -7$))) \times$ growth rate (Dennis et al. 2012)

The longer the rotation length, the smaller the proportion of growth that was missed each grazing and, therefore, the smaller the adjustment factor. Data correction was not required for Woodlands or COAST. For Woodlands, growth rate was determined using cage cuts and on the COAST farm grazing date and post-grazing cover were included in the Pasture Coach calculations of growth rate.

At the commencement of the project, the Woodlands long-term average annual pasture DM production was $12.9 \mathrm{t} \mathrm{DM} / \mathrm{ha}$, however during the project this site averaged $11.0 \pm 0.38 \mathrm{t} \mathrm{DM} / \mathrm{h}$. When the monitor farm data was corrected for grazing date only the NORTH site grew less pasture than the long-term Woodlands average, but it was comparable with growth at Woodlands during the monitoring period. The

Table 2. Average (s.d.) monthly growth rate and annual pasture dry matter production (kg/ha) recorded from seven locations across Southland and south and west Otago from August 2007 to May 2012 and adjusted annual dry matter production.

\begin{tabular}{lccccccc}
\hline & Woodlands & $\begin{array}{c}\text { Central } \\
\text { Southland }\end{array}$ & $\begin{array}{c}\text { Eastern South- } \\
\text { land }\end{array}$ & $\begin{array}{c}\text { Coastal } \\
\text { Southland }\end{array}$ & $\begin{array}{c}\text { Northern } \\
\text { Southland }\end{array}$ & West Otago South Otago \\
\hline June & $7(4.1)$ & $5(2.5)$ & $7(2.5)$ & $9(2.8)$ & $2(1.9)$ & $4(1.8)$ & $10(1.7)$ \\
July & $4(2.2)$ & $4(2.1)$ & $4(1.0)$ & $7(4.1)$ & $1(0.5)$ & $5(1.7)$ & $3(0.0)$ \\
August & $9(2.0)$ & $12(1.5)$ & $13(5.9)$ & $17(5.4)$ & $9(2.1)$ & $13(3.3)$ & $12(2.0)$ \\
September & $21(2.9)$ & $33(5.8)$ & $35(7.2)$ & $41(11.3)$ & $24(7.1)$ & $28(6.9)$ & $28(6.7)$ \\
October & $42(9.2)$ & $49(7.3)$ & $53(6.9)$ & $60(4.4)$ & $43(12.3)$ & $50(7.3)$ & $46(5.6)$ \\
November & $64(11.5)$ & $53(14.1)$ & $51(10.8)$ & $68(8.5)$ & $45(10.5)$ & $50(9.2)$ & $50(13.8)$ \\
December & $51(8.6)$ & $29(5.9)$ & $42(8.2)$ & $55(16.4)$ & $22(8.5)$ & $34(6.8)$ & $45(9.9)$ \\
January & $45(14.8)$ & $35(11.8)$ & $40(9.6)$ & $51(17.4)$ & $26(13.7)$ & $38(10.0)$ & $48(13.3)$ \\
February & $49(15.4)$ & $38(14.5)$ & $44(12.9)$ & $50(17.4)$ & $25(14.8)$ & $39(16.2)$ & $41(6.2)$ \\
March & $45(9.3)$ & $34(10.5)$ & $47(7.4)$ & $50(9.9)$ & $24(8.9)$ & $36(6.3)$ & $41(3.9)$ \\
April & $34(10.1)$ & $28(2.1)$ & $38(6.0)$ & $42(9.5)$ & $17(3.9)$ & $26(2.1)$ & $31(2.1)$ \\
May & $14(3.0)$ & $13(6.7)$ & $16(6.2)$ & $21(6.7)$ & $10(4.3)$ & $13(3.2)$ & $23(5.4)$ \\
& & & & & & $14.3)$ \\
Annual pasture DM & $11.0(0.38)$ & $10.1(0.21)$ & $11.8(0.21)$ & $14.3(0.27)$ & $7.6(0.22)$ & $10.2(0.18)$ & $11.5(0.17)$ \\
Adjusted annual DM & - & $13.7(0.27)$ & $15.6(0.29)$ & - & $10.4(0.31)$ & $14.1(0.25)$ & $14.7(0.22)$ \\
\hline
\end{tabular}


higher growth rates at the EAST site, which is closest geographically to Woodlands, is most likely to be the result of differences in grazing management and the use of nitrogen fertiliser on the EAST farm.

The average annual pasture growth recorded in the current project were within the range reported by Radcliffe (1974) from monitoring sites at Mona Bush and Winton. At Mona Bush the average annual DM yield was $14.6 \mathrm{t} \mathrm{DM} /$ ha with a range from 10.2 to $17.3 \mathrm{t} \mathrm{DM} / \mathrm{ha}$ in the lowest and highest growth years respectively. At Winton the average annual production was $12.0 \mathrm{t} \mathrm{DM} /$ ha with the lowest and highest years recording 8.9 and $16.0 \mathrm{t} \mathrm{DM/ha,} \mathrm{respectively.}$

Soil temperature trends were very similar between the regions (Figure 2) with average temperatures of less than $5^{\circ} \mathrm{C}$ being recorded in June and July and above $15^{\circ} \mathrm{C}$ recorded through December, January and February.

Average pasture dry matter percentage (DM\%) ranged from 13 to $28 \%$ with higher $\mathrm{DM} \%$ being observed during winter on all farms and during the summer months in EAST, NTH and WO (Table 3). CENT had the least variation in pasture DM\% of the four farms monitored. There were large differences in pasture crude protein percentages $(\mathrm{CP} \%)$ recorded between the farms. Average $\mathrm{CP} \%$ ranged from $20 \%$ in NTH in December to $30 \%$ in CENT in April and EAST in May. Sixty-five percent of the pasture samples collected had a $\mathrm{CP} \%$ greater than 25 , and $96 \%$ of the samples were greater than $20 \%$ CP. Maximum dietary protein requirement for lactating cows is approximately $20 \%$, indicating that a large percentage of the samples collected were supplying excess dietary protein. On all farms the trend was for pasture $\mathrm{CP} \%$ to increase through the autumn period, most likely in response to the application of $\mathrm{N}$ fertiliser or, in the case of the NTH farm, the application of bedding material and effluent from the wintering barn. Neutral detergent fibre concentrations (NDF) were highly variable and showed no real trends. The highest NDF values were recorded during late spring and summer following the pastures entering the reproductive phase and also during the period when pasture growth was often limited by moisture stress. Northern Southland recorded the lowest average metabolisable energy (ME) concentration through the summer period (Table 3), however EAST and WO also recorded lower energy concentrations during this period.

Table 3. Average (s.d.) monthly pasture dry matter (DM\%), crude protein (CP\%), neutral detergent fibre (NDF\%) and metabolisable energy (ME, MJ/kg) from four monitor farms in central Southland (Cent), eastern Southland (East), northern Southland (Nth) and west Otago (WO) from Aug 2007 to May 2010.

\begin{tabular}{|c|c|c|c|c|c|c|c|c|c|c|c|c|c|c|c|c|}
\hline & \multicolumn{4}{|c|}{ (\%) } & \multicolumn{4}{|c|}{ Srude pro } & \multicolumn{4}{|c|}{ etergent fibre (\%) } & \multicolumn{4}{|c|}{$\begin{array}{c}\text { Metabolisable Energy (MJ/ } \\
\text { kg DM) }\end{array}$} \\
\hline & ent & ast & & WO & nt & Ea & Nth & WOt & t & ast & $\mathrm{N}$ & WOt & Cent & East & $y+1$ & NOt \\
\hline & & $.7)$ & & 2 & 4) & $\begin{array}{c}25 \\
(0.8)\end{array}$ & 4) & (1.4) & (U.0) & 8) & (U.Y) & (3.3) & & & & \\
\hline Jul & $\begin{array}{r}10 \\
(0 .\end{array}$ & $\begin{array}{c}17 \\
(0.7)\end{array}$ & & $\begin{array}{c}19 \\
(6.0)\end{array}$ & $\begin{array}{c}27 \\
(1.2)\end{array}$ & $\begin{array}{c}25 \\
(1.1)\end{array}$ & $.8)$ & (3.3) & (1.1) & $\begin{array}{l}48 \\
3.3)\end{array}$ & (1.6) & (1.6) & & & & $\begin{array}{c}12.0 \\
(0.42)\end{array}$ \\
\hline & $\begin{array}{r}2 \\
(1 .\end{array}$ & $\begin{array}{c}16 \\
(1.0)\end{array}$ & & 1 & $\begin{array}{l}27 \\
(4.1)\end{array}$ & $\begin{array}{c}25 \\
(1.6)\end{array}$ & $\begin{array}{l}25 \\
(1.6)\end{array}$ & $\begin{array}{c}25 \\
(1.8)\end{array}$ & $\begin{array}{l}41 \\
(2.0)\end{array}$ & $\begin{array}{l}44 \\
1.5)\end{array}$ & $\begin{array}{c}42 \\
(5.4)\end{array}$ & $\begin{array}{c}46 \\
(2.7)\end{array}$ & & & & $\begin{array}{l}11.8 \\
.23)\end{array}$ \\
\hline $\mathrm{Se}$ & $\begin{array}{r}20 \\
(1.3\end{array}$ & $\begin{array}{c}18 \\
(2.6)\end{array}$ & (v) & $\begin{array}{c}18 \\
(1.3)\end{array}$ & $\begin{array}{c}26 \\
(3.9)\end{array}$ & $\begin{array}{c}26 \\
(0.5)\end{array}$ & $\begin{array}{c}28 \\
(2.4)\end{array}$ & $\begin{array}{c}25 \\
(2.5)\end{array}$ & $\begin{array}{c}44 \\
(1.7)\end{array}$ & $\begin{array}{c}47 \\
(2.3)\end{array}$ & $\begin{array}{c}41 \\
(1.0)\end{array}$ & $\begin{array}{c}44 \\
(2.3)\end{array}$ & & & & $\begin{array}{l}12.3 \\
(0.28)\end{array}$ \\
\hline Oc & $\begin{array}{l}17 \\
(2 .\end{array}$ & $\begin{array}{c}17 \\
(1.5)\end{array}$ & & 15 & $\begin{array}{c}25 \\
(1.5)\end{array}$ & $\begin{array}{c}26 \\
(2.6)\end{array}$ & $\begin{array}{c}28 \\
(1.3)\end{array}$ & $\begin{array}{c}29 \\
(1.1)\end{array}$ & $\begin{array}{c}40 \\
(1.6)\end{array}$ & $\begin{array}{c}44 \\
(1.3)\end{array}$ & 4 & $\begin{array}{c}41 \\
(2.3)\end{array}$ & & & & $\begin{array}{l}2.3 \\
.14)\end{array}$ \\
\hline & $\begin{array}{c}18 \\
(0.6)\end{array}$ & $\begin{array}{c}15 \\
(1.3)\end{array}$ & 涼 & $\begin{array}{c}16 \\
(0.6)\end{array}$ & $\begin{array}{c}24 \\
(3.7)\end{array}$ & $\begin{array}{c}25 \\
(4.9)\end{array}$ & $\begin{array}{c}24 \\
(3.8)\end{array}$ & $\begin{array}{c}26 \\
(4.5)\end{array}$ & $\begin{array}{c}43 \\
(3.1)\end{array}$ & $\begin{array}{c}45 \\
(2.0)\end{array}$ & $\begin{array}{c}43 \\
(3.4)\end{array}$ & $\begin{array}{c}42 \\
(2.4)\end{array}$ & & $\begin{array}{l}12.0 \\
(0.63)\end{array}$ & & $\begin{array}{c}12.2 \\
(0.41)\end{array}$ \\
\hline $\mathrm{De}$ & $\begin{array}{c}20 \\
(0.6)\end{array}$ & $\begin{array}{c}14 \\
(0.5)\end{array}$ & & $\begin{array}{c}18 \\
(1.4)\end{array}$ & $\begin{array}{l}21 \\
(2.9)\end{array}$ & $\begin{array}{c}25 \\
(1.9)\end{array}$ & $\begin{array}{l}20 \\
(4.0)\end{array}$ & $\begin{array}{c}25 \\
(1.1)\end{array}$ & $\begin{array}{c}48 \\
(3.6)\end{array}$ & $\begin{array}{c}44 \\
(1.6)\end{array}$ & $\begin{array}{c}52 \\
(3.8)\end{array}$ & $\begin{array}{c}46 \\
(4.0)\end{array}$ & & $\begin{array}{l}.9 \\
\text { 29) }\end{array}$ & & $\begin{array}{c}11.7 \\
(0.34)\end{array}$ \\
\hline Ja & $\begin{array}{c}17 \\
(0.7)\end{array}$ & $\begin{array}{c}15 \\
(1.0)\end{array}$ & 20 & 19 & $\begin{array}{c}28 \\
(4.1)\end{array}$ & $\begin{array}{c}26 \\
(3.2)\end{array}$ & $\begin{array}{c}22 \\
(1.9)\end{array}$ & $\begin{array}{c}27 \\
(2.6)\end{array}$ & $\begin{array}{c}42 \\
(1.2)\end{array}$ & $\begin{array}{c}45 \\
(0.8)\end{array}$ & $\begin{array}{c}48 \\
(0.7)\end{array}$ & $\begin{array}{c}44 \\
(3.9)\end{array}$ & & $\begin{array}{c}11.5 \\
(0.60)\end{array}$ & & $\begin{array}{c}11.2 \\
(0.75)\end{array}$ \\
\hline Fet & $\begin{array}{c}20 \\
(1.5)\end{array}$ & $\begin{array}{c}17 \\
(4.7)\end{array}$ & $\begin{array}{c}28 \\
(4.7)\end{array}$ & $\begin{array}{c}17 \\
(1.5)\end{array}$ & $\begin{array}{c}29 \\
(2.9)\end{array}$ & $\begin{array}{l}27 \\
(0.2)\end{array}$ & $\begin{array}{c}21 \\
(1.3)\end{array}$ & $\begin{array}{c}27 \\
(0.6)\end{array}$ & $\begin{array}{c}42 \\
(2.1)\end{array}$ & $\begin{array}{c}46 \\
(2.4)\end{array}$ & $\begin{array}{c}52 \\
(5.8)\end{array}$ & $\begin{array}{c}47 \\
(2.8)\end{array}$ & & $\begin{array}{c}11.8 \\
(0.53)\end{array}$ & $\begin{array}{l}10 \\
(0 .\end{array}$ & $\begin{array}{l}11.3 \\
(0.24)\end{array}$ \\
\hline $\mathrm{N}$ & $\begin{array}{c}17 \\
(1.1)\end{array}$ & $\begin{array}{c}14 \\
(2.3)\end{array}$ & $\begin{array}{c}20 \\
(3.9)\end{array}$ & $\begin{array}{c}15 \\
(0.6)\end{array}$ & $\begin{array}{c}28 \\
(2.6)\end{array}$ & $\begin{array}{c}28 \\
(1.5)\end{array}$ & $\begin{array}{c}25 \\
(3.4)\end{array}$ & $\begin{array}{c}29 \\
(3.9)\end{array}$ & $\begin{array}{c}45 \\
(4.1)\end{array}$ & $\begin{array}{c}48 \\
(1.9)\end{array}$ & $\begin{array}{c}47 \\
(3.9)\end{array}$ & $\begin{array}{c}46 \\
(1.3)\end{array}$ & $\begin{array}{l}12 \\
(0 . C\end{array}$ & $\begin{array}{c}11.7 \\
(0.26)\end{array}$ & & $\begin{array}{l}11.5 \\
(0.36)\end{array}$ \\
\hline Apr & $\begin{array}{c}16 \\
(1.4)\end{array}$ & $\begin{array}{c}13 \\
(0.5)\end{array}$ & $\begin{array}{c}17 \\
(2.1)\end{array}$ & $\begin{array}{c}14 \\
(0.7)\end{array}$ & $\begin{array}{c}30 \\
(1.5)\end{array}$ & $\begin{array}{c}29 \\
(1.0)\end{array}$ & $\begin{array}{c}27 \\
(0.4)\end{array}$ & $\begin{array}{c}29 \\
(2.3)\end{array}$ & $\begin{array}{c}40 \\
(1.7)\end{array}$ & $\begin{array}{c}44 \\
(1.3)\end{array}$ & $\begin{array}{c}43 \\
(1.2)\end{array}$ & $\begin{array}{c}44 \\
(3.2)\end{array}$ & $\begin{array}{c}12.5 \\
(0.07)\end{array}$ & $\begin{array}{c}12.1 \\
(0.23)\end{array}$ & & $\begin{array}{c}12.0 \\
(0.28)\end{array}$ \\
\hline $\mathrm{Ma}$ & $\begin{array}{c}17 \\
(2.1)\end{array}$ & $\begin{array}{c}15 \\
(2.0)\end{array}$ & $\begin{array}{c}18 \\
(1.6)\end{array}$ & $\begin{array}{c}16 \\
(2.0)\end{array}$ & $\begin{array}{c}29 \\
(2.0)\end{array}$ & $\begin{array}{c}30 \\
(1.8)\end{array}$ & $\begin{array}{c}26 \\
(1.6)\end{array}$ & $\begin{array}{c}28 \\
(3.3)\end{array}$ & $\begin{array}{c}39 \\
(2.1)\end{array}$ & $\begin{array}{c}41 \\
(3.0)\end{array}$ & $\begin{array}{c}42 \\
(2.6)\end{array}$ & $\begin{array}{c}45 \\
(3.5)\end{array}$ & $\begin{array}{c}11.9 \\
(0.21)\end{array}$ & $\begin{array}{c}11.8 \\
(0.55)\end{array}$ & $\begin{array}{c}11.9 \\
(0.35)\end{array}$ & $\begin{array}{c}11.6 \\
(0.23)\end{array}$ \\
\hline
\end{tabular}




\section{Conclusions}

Pasture growth rate and quality varied between regions and between years within a region making it difficult to predict annual pasture production reliably. While average regional data would be acceptable for farmers looking to set feed budgets and assess the stocking rate and calving date for their farms, for farmers wanting to optimise the pasture management on their farm, weekly monitoring of pasture cover is essential.

\section{Acknowledgements}

The input of George \& Jose van der Poel, Dave \& Mel Goble, Kevin \& Debbie Hall and Adrian \& Isabelle Frei, owners of the four monitor farms, the Southland Demonstration Farm and Telford Dairy Farm for allowing us access to their farm and being prepared to have their data available for use by others, is gratefully acknowledged. Thanks to Noel May and Gordon Baxter for assisting with the data collection during the project. Funding for the project was provided by the MAF Sustainable Farming Fund, SIDE, DairyNZ and Ravensdown.

\section{REFERENCES}

DairyNZ. 2011. New Zealand Dairy Statistics 2010-11. Accessed January 2012. http://www.lic.co.nz/pdf/ DAIRY\%20STATISTICS\%2010-11-WEB.pdf
Dennis, S.J.; McDowell, R.W.; Stevens, D.R.; Dalley, D. 2012. Opportunities to decrease the water quality impact of spring forage crops on dairy farms. Proceedings of the New Zealand Grasslands Association 74: 45-50.

Parsons, A.J. 1994. Exploiting resource capture - grassland. pp 315-349 In: Resource Capture by Crops. Eds. J.L. Monteith, R.K. Scott, M.H. Unsworth. Nottingham University Press.

Radcliffe, J.E. 1974. Seasonal distribution of pasture production in New Zealand. II Southland Plains. New Zealand Journal of Experimental Agriculture 2: 341-348.

Thomson, N.A.; Upsdell, M.P.; Hooper, R.; Henderson, H.V.; Blackwell, M.B.; McCallum, D.A.; Hainsworth. R.J.; Macdonald, K.A.; Wildermoth, D.D.; BishopHurley, G.J.; Penno, J.W. 2001. Development and evaluation of a standardised means for estimating herbage mass of dairy pastures using the rising plate meter. Proceedings of the New Zealand Grasslands Association 63: 149-157.

Smith, L.C. 2012. Long term pasture growth patterns for Southland New Zealand: 1978 to 2012. Proceedings of the New Zealand Grasslands Association 74: 147-152. 
